\title{
PENGARUH LINGKUNGAN TEMAN SEBAYA TERHADAP MOTIVASI BELAJAR SANTRI MDT AT-TAQWA KP. RANCA AYU DESA MAROKO KABUPATEN GARUT
}

\author{
Sri Utami Dewi \\ IAIC Tasikmalaya \\ sriutami@iaic.ac.id
}

\begin{abstract}
Relatioanships with peers have a number of important roles in the development of personal and social development. The most important functions of peers is to provide resources and comparison about the world outside the family. Children receive feedback on their capabilities of its peer group. The interaction among student both in the classroom formed an association which may be one source of extrinsic motivation, namely peers. Togethemess within long time at school can provide its own motivation in the learning process. The purpose of this study is to: (1) explain the level of peer interaction of fifth grade stundents of MDT At-taqwa kp. Ranca Ayu desa Maroko Kab. Garut, (2) explain the motivation level of the fifth students at state MDT Attaqwa kp. Ranca Ayu desa Maroko Kab. Garut, (3) determine the between peer interaction with students motivation in fifth grade state MDT At-taqwa kp. Ranca Ayu desa Maroko Kab. Garut. The results showed that the higher level of peer interaction of the students, the higher students motivation.
\end{abstract}

Keywords: Interaction Peers, Motivation.

\section{Abstrak}

Hubungan dengan teman sebaya memiliki sejumlah peran penting dalam perkembangan pribadi dan sosial anak. Salah satu fungsi terpenting teman sebaya yaitu memberikan sumber informasi dan perbandingan tentang dunia di luar keluarga. Anak-anak menerima 
umpan balik tentang kemampuan mereka dari grup sebayanya. Dengan adanya interaksi antar santri baik dikelas maupun di luar kelas terbentuklah suatu perkumpulan yang dapat dijadikan salah satu sumber motivasi ekstrinsik, yaitu teman sebaya. Kebersamaan dengan waktu yang lama di madrasah dapat memberikan motivasi tersendiri dalam proses belajar. Tujuan penelitian ini adalah untuk: (1) menjelaskan tingkat interaksi teman sebaya santri di MDT At-taqwa kp. Ranca Ayu desa Maroko Kab. Garut, (2) menjelaskan tingkat motivasi belajar santri di MDT At-taqwa kp. Ranca Ayu desa Maroko Kab. Garut, (3) mengetahui hubungan antara interaksi teman sebaya dengan motivasi belajar santri di MDT At-taqwa kp. Ranca Ayu desa Maroko Kab. Garut. Hasil penelitian menunjukkan bahwa semakin tinggi tingkat interaksi teman sebaya yang dimiliki santri, maka semakin tinggi pula motivasi belajar santri.

Kata kunci: interaksi teamn sebaya, Motivasi belajar.

\section{PENDAHULUAN}

\section{Latar Belakang Penelitian}

Seseorang yang belajar pasti membutuhkan motivasi baik yang berasal dari diri sendiri dan dari luar diri atau lingkungan. Dengan adanya motivasi belajar yang tinggi mengakibatkan hasil yang diperoleh akan lebih baik. Menurut Badrudin "Motivasi adalah kondisi psikologis dalam diri individu yang menggerakkan individu untuk bertindak sehingga terjadi perubahan tingkah laku yang didasari untuk mencapai tujuan".

Motivasi belajar dapat juga dikatakan sebagai semangat untuk belajar yang biasanya diwujudkan dalam tindakan-tindakan positif seperti berlatih keras mengerjakan soal-soal untuk mengasah kemampuannya serta giat mencari reverensi-reverensi. Adanya motivasi belajar memungkinkan santri untuk tidak berputus asa dalam mencapai keinginannya dalam mempelajari suatu ilmu sehingga memperoleh prestasi yang optimal.

Lingkungan teman sebaya merupakan lingkungan bersentuhan langsung dengan kehidupan santri setiap harinya. Intensitas pertemuan antar santri dimadrasah yang tinggi, memiliki pengaruh yang besar 
dalam suasana pembelajaran. Teman sebaya mampu memberikan motivasi sekaligus suasana yang membangun ababila berada didalam kelas. santri juga lebih merasa nyaman jika belajar ataupun bertanya mengenai materi pembelajaran dengan teman sebaya karena apabila bertanya dengan guru biasanya akan muncul suatu ketakutan tersendiri.

Lingkungan teman sebaya merupakan salah satu faktor yang mempengaruhi motivasi belajar santri di MDT At-taqwa kp. Ranca Ayu, desa Maroko, Kab. Garut. Lingkungan teman sebaya merupakan lingkungan dimana terjadinya suatu interaksi yang intensif dan cukup teratur dengan orang-orang yang mempunyai kesamaan dalam usia dan status, yang memberikan dampak atau pengaruh positif maupun negatif yang dikarenakan interaksi didalamnya.

Berdasarkan observasi yang telah dilakukan ternyata masih saja terdapat santri yang kurang motivasi dalam hal belajar. Pergaulan santri dengan teman-temannya, baik dirumah maupun dimadrasah, mempengaruhi motivasi anak dalam belajar. Anak yang malas untuk hadir ke madrasah menjadikan sebagian santri lainnya enggan untuk hadir pula ke madrasah. Hal ini menyebabkan prestasi belajar anak menjadi kurang optimal.

Lingkungan teman sebaya mempengaruhi motivasi belajar anak di MDT At-taqwa kp. Ranca Ayu, desa Maroko, Kab. Garut. Hal ini dapat dilihat dari kenyataan yang ada pada saat ini, banyak anak yang lebih tergantung dalam hal-hal negarif dengan teman sebaya seperti tidak mengingatkan dalam belajar atau bercanda pada saat kegiatan belajar mengajar, banyaknya anak yang jarang mengerjakan tugas karena ikutikutan temannya, sebagian anak lebih asyik mengobrol dengan teman sebelahnya daripada mendengarkan guru yang sedang menjelaskan didepan kelas.

Berdasarkan latar belakang masalah diatas, terdapat keterkaitan antara motivasi belajar dengan lingkungan teman sebaya terhadap motivasi belajar. Berdasarkan pengamatan tersebut, peneliti tertarik untuk meneliti masalah ini kedalam skripsi dengan judul "PENGARUH LINGKUNGAN TEMAN SEBAYA TERHADAP MOTIVASI BELAJAR SANTRI MDT AT-TAQWA KP. RANCA AYU DESA MAROKO KABUPATEN GARUT". 


\section{Kajian Literatur Penelitia}

\section{Lingkungan Teman Sebaya}

a. Pergaulan Kelompok Teman Sebaya

Lingkungan tepat tinggal mengajarkan berbagai macam hal kehidupan kepada manusia. Salah satu untuk mengenal satu sama lain dengan antar individu. Manusia dituntut untuk dapat mandiri dalam mengerjakan kegiatannya, manusia juga dituntut untuk mampu berinteraksi dengan individu lain. Karena dalam kehidupannya manusia tidak bisa hidup tanpa bantuan orang lain. Pergaulan merupakan proses antar individu yang satu dengan yang lain yang terjalin secara langsung yang melakukan hubungan interaksi dan jika dilakukan dalam jangka waktu tertentu akan membentuk jalinan persahabatan atau pertemanan. Dari pergaulan yang dilakukan oleh siswa, maka siswa mulai mengenal berbagai pihak yang terdapat dalam lingkungan pergaulan tersebut. Salah satunya adalah teman sebaya. Menurut Santrock (2009:109) teman sebaya adalah anak-anak dengan usia atau tikat kedewasaan yang kurang lebih sama. Lingkungan teman sebaya merupakan suatu interaksi dengan orang-orang yang mempunyai kesamaan dalam usia, status sosial, hobi dan pemikiran yang sama, dalam berinteraksi mereka akan mempertimbangkan dan lebih memilih bergabung dengan orang-orang yang mempunyai kesamaan dalam hal-hal tersebut (Robert E.Slavin, 2011: 114). Dalam kelompok teman sebaya individu akan merasakan adanya persamaan satu dengan yang baik usia, status sosial, kebutuhan, dan tujuan untuk memperkuat kelompok itu, sehingga individu didalam kelompok tersebut akan merasa menemukan dirinya dan akan mengembangkan rasa sosialnya seiring dengan perkembangan kepribadiannya (Slamet Santosa, 2009: 77).

Dapat disimpulkan bahwa kelompok teman sebaya adalah kelompok sosial yang terbentuk karena individu satu dengan lainnya mempunyai persamaan usia, status sosial, jenis kelamin, kebutuhan serta minat yang membuat individu yang bergabung didalam kelompok tersebut menjadi nyaman. Jadi pergaulan kelompok teman sebaya adalah hubungan interaksi sosial yang timbul karena individu-individu yang berkumpul dan membentuk suatu kelompok yang didasarkan pada persamaan usia, 
status sosial, kebutuhan serta minat yang seiring berjalannya waktu akan membentuk pertemanan atau persahabatan.

b. Indikator Pergaulan Kelompok Teman Sebaya

Pergaulan kelompok teman sebaya adalah hubungan interaksi sosial yang timbul karena individu-individu yang berkumpul dan membentuk suatu kelompok yang didasarkan pada persamaan usia, status sosial, kebutuhan serta minat yang seiring berjalannya waktu akan membentuk pertemanan atau persahabatan. Dari penjelasan kajian teori Pergaulan Kelompok Teman Sebaya, maka dapat diperoleh kesimpulan mengenai indikator Pergaulan Kelompok Teman Sebaya adalah sebagai berikut:

1) Teman sebagai pengganti keluarga

Furman dan Buhrmester (1992) dalam Santrock mengatakan bahwa anak remaja lebih bergantung pada teman-teman mereka daripada degan orang tua mereka untuk memuaskan kebutuhan pertemanan, perasaan berharga dan keintiman kasih sayang.

2) Belajar memecahkan masalah

Salah satu fungsi dan peranan teman sebaya menurut Slamet Santosa adalah belajar saling bertukar perasaan dan masalah. Mereka saling menumpahkan perasaan dan permasalahan yang tidak bisa mereka ceritakan pada orang tua maupun guru mereka. Dalam peer group, individu dapat mencapai ketergantungan satu sama lain. Karena dalam peer group ini mereka dapat merasakan kebersamaan dalam kelompok, mereka saling tergantung satu sama lainnya.

3) Memperoleh dorongan emosional

Salah satu fungsi positif dari teman sebaya menurut Kelly dan Hansen (1987) dalam Desmita adalah memperoleh dorongan emosional dan sosial serta menjadi lebih independen.

4) Menjadi teman belajar anak

Seperti yang telah dijelaskan Desmita bahwa salah satu faktor yang mempengaruhi terbentuknya kelompok teman sebaya adalah kegiatan atau aktivitas yang sama, tinggal di lingkungan yang sama, bersekolah di sekolah yang sama dan berpartisipasi dalam organisasi yang sama. Salah satu bentuk kegiatan atau aktivitas bersama berdasar lingkungan bersekolah ditempat yang sama adalah belajar bersama, sehingga teman sebaya akan menjadi teman belajar santri. 
5) Meningkatkan harga diri anak

Salah satu fungsi positif dari teman sebaya menurut Kelly dan Hansen (1987) dalam Desmita adalah meningkatkan harga diri. Indikator tersebut akan digunakan untuk mengetahui seberapa besar pengaruh lingkungan teman sebaya terhadap motivasi belajar santri MDT At-taqwa, kp. Ranca Ayu, desa Maroko, Kab. Garut.

c. Latar Belakang Timbulnya Kelompok Teman sebaya

Dalam kehidupan sehari-hari individu hidup didalam tiga lingkungan yaitu keluarga, sekolah dan masyarakat. Menurut Havinghurst dalam Slamet Santosa (2009: 77) anak tumbuh dan berinteraksi dalam dua dunia yaitu dunia orang dewasa dan dunia teman sebayanya. Dunia orang dewasa meliputi orang tuanya, gurunya, dan tetangganya, sedangkan dunia teman sebayanya meliputi kelompok permainan, kelompok teman di sekolah, dan teman-temannya. Interaksi teman sebaya dari kebanyakan anak usia sekolah ini terjadi dalam grup atau kelompok, sehingga periode ini sering disebut usia kelompok.

Dalam menentukan sebuah kelompok teman, dasar bagi kemungkinan terbentuknya kelompok teman sebaya adalah tinggal di lingkungan yang sama, bersekolah di sekolah yang sama, dan berpartisipasi dalam organisasi masyarakat yang sama. Sehingga seorang siswa lebih mementingkan aktivitas yang dilakukan bersamasama, misalnya berbicara, berkeluyuran, berjalan ke sekolah, berbicara melalui telepon, mendengarkan musik, bermain game, dan melucu (Desmita, 2014: 224).

Jadi dapat disimpulkan latar belakang terbentuknya kelompok teman sebaya karena adanya kegiatan yang dilakukan secara bersamasama, adanya kebutuhan yang sama, memiliki tujuan yang sama untuk mencari identitas diri dan ingin melakukan interaksi yang lebih banyak dengan teman sebaya dibandingkan orang tua. Setelah terbentuknya kelompok teman sebaya lama kelamaan akan timbul hubungan pertemanan atau persahabatan.

Para ahli perkembangan yaitu Rubin, Bukowski dalam Santrock (2009: 112) menemukan lima jenis status teman sebaya. Lima jenis status teman sebaya yang ditemukan adalah sebagai berikut: 
1) Anak-anak populer (popular children), seringkali dipilih sebagai kawan terbaik dan jarang tidak disukai oleh kawannya.

2) Anak biasa, anak yang tidak sering disukai juga anak yang tidak sering tidak disukai.

3) Anak rata-rata (average children), memperoleh angka rata-rata untuk dipilih secara positif dan negatif oleh kawan-kawannya.

4) Anak-anak yang ditolak (rejected children), jarang dipilih sebagai kawan terbaik seseorang dan secara aktif tidak disukai oleh kawankawannya.

5) Anak-anak kontroversial (controversial children), mungkin dipilih sebagai kawan terbaik seseorang atau mungkin pula tidak disukai oleh kawan-kawannya. Sahabat dapat bertindak sebagai orang yang terpercaya dan dapat membantu dalam mengatasi masalah-masalah. Pemberian dukungan dapat berupa dukungan emosi serta nasehat berupa informasi.

d. Fungsi Pergaulan Kelompok Teman Sebaya

Pada prinsipnya hubungan lingkungan teman sebaya mempunyai arti sangat penting bagi remaja. Menurut Jean Piaget dan Harry Stack S dalam Desmita (2014: 230) menekankan bahwa melalui teman sebaya anak dan remaja belajar tentang hubungan timbal balik yang sistematis. Anak mempelajari prinsip-prinsip kejujuran dan keadilan melalui peristiwa pertentangan dengan remaja. Mereka juga mempelajari secara aktif kepentingan-kepentingan dan perspektif teman sebaya dalam rangka memuluskan integrasi dirinya dalam aktifitas teman sebaya yang berkelanjutan. Santrock (2009: 109) mengatakan bahwa salah satu fungsi yang terpenting dari kelompok teman sebaya adalah untuk memberikan sumber informasi dan perbandingan tentang dunia di luar lingkungan keluarga. Menurut Slamet Santosa (2009: 79) fungsi kelompok teman sebaya adalah sebagai berikut:

1) Mengajarkan kebudayaan.

2) Mengajarkan mobilitas sosial.

3) Membantu peranan sosial yang baru.

4) Kelompok teman sebaya sebagai sumber informasi bagi orang tua, guru bahkan masyarakat. 
5) Dalam kelompok teman sebaya individu dapat mencapai ketergantungan satu sama lain.

6) Kelompok teman sebaya mengajarkan moral orang dewasa.

7) Mencapai kebebasan sendiri.

6 fungsi positif dari teman sebaya menurut Kelly dan Hansen (1987) dalam Desmita (2014: 230-231):

1) Mengontrol impuls-impuls agresif.

2) Memperoleh dorongan emosional dan sosial serta menjadi lebih independen.

3) Meningkatkan keterampilan-keterampilan sosial, mengembangkan kemampuan penalaran dan belajar untuk mengekspresikan perasaan dengan cara lebih matang.

4) Mengembangkan sikap terhadap seksualitas dan tingkah laku peran jenis kelamin.

5) Memperkuat penyesuaian moral dan nilai-nilai.

6) Meningkatkan harga diri.

Sementara dampak negatif yang ditimbulkan adalah adanya sebagian anak remaja yang ditolak atau diabaikan oleh teman sebaya yang dapat menimbulkan permusuhan dan menimbulkan perasaan kesepian yang bisa mengganggu perkembangan anak tersebut, timbulnya rasa iri dan persaingan pada anggota kelompok yang tidak memiliki kesamaan dengan dirinya, timbulnya pertentangan antar kelompok teman sebaya (Slamet Santosa, 2009: 82).

\section{Motivasi Belajar}

a. Pengertian Motivasi Belajar

Menurut Dalyono, "Motivasi merupakan daya penggerak atau pendorong untuk melakukan suatu pekerjaan". Motivasi merupakan perubahan-perubahan yang ada dalam diri siswa yang ditandai dengan kemunculan perasaan dan didahului dengan adanya tujuan, munculnya perasaan itu karena adanya rangsangan oleh unsur lain. Menurut Oemar Hamali "Perubahan energi dalam diri seseorang yang ditandai dengan timbulnya perasaan dan reaksi untuk mencapai tujuan". Motivasi merupakan suatu yang bersifat kompleks. Motivasi memegang peranan penting dalam pencapaian prestasi belajar seseorang. Menurut Hamzah 
B Uno "Motivasi belajar merupakan dorongan dari dalam diri dan dari eksternal dari mahasiswa-mahasiswa yang sedang belajar dalam rangka merubah tingkah laku yang didukung oleh unsur-unsur lain yang mendukungnya". Dari uraian di atas maka dapat disimpulkan bahwa motivasi belajar akuntansi adalah keseluruhan daya penggerak yang berasal dari dalam diri siswa maupun dari luar diri siswa yang menciptakan serangkaian usaha untuk dapat mencapai tujuan yang dikehendaki dalam kegiatan belajar mahasiswa.

b. Indikator Motivasi Belajar

Adapun yang menjadi indikator motivasi belajar adalah sebagai berikut:

1) Tekun dalam menghadapi tugas-tugas

Dapat mengerjakan secara kontinyu dalam durasi yang lama, dan tidak berhenti sebelum tugas tersebut selesai.

2) Ulet menghadapi kesulitan

Tidak mudah putus asa dan tidak memerlukan dorongan dari luar siswa dalam berprestasi (tidak cepat puas dengan apa yang telah dicapai).

3) Mandiri

Lebih senang bekerja dan mengerjakan secara mandiri dan tidak bergantung dengan orang lain.

4) Menyukai hal-hal baru

Lebih cepat bosan dengan tugas yang selalu sama atau berulang-ulang begitu saja. Senang mencari dan memecahkan masalah soal-soal.

5) Konsisten

Jika sudah yakin akan sesuatu maka siswa dapat mempertahankan pendapatnya. Tidak mudah melepas dalam berpendapat yang diyakini.

\section{METODE}

Jenis penelitian yang digunakan dalam penelitian ini adalah deskriptif kuantitatif dengan lokasi penelitian adalah MDT At-Taqwa Kp. Ranca Ayu Desa Maroko Kab. Garut. Subyek penelitian dalam penelitian ini adalah kenakalan peserta didik MDT At-Takwa. Sebagai penambah informasi untuk melengkapi data yang diperlukan, maka digali informasi dari informan yang terdiri dari Kepala Sekolah, guru, dan orang tua peserta didik. Pengumpulan data dan informasi dalam 
penelitian ini menggunakan teknik wawancara, observasi dan dokumentasi. Analisis data melalui tahapan reduksi, penyajian dan penarikan kesimpulan.

\section{TEMUAN DAN PEMBAHASAN}

a) Tingkat Interaksi Teman Sebaya Santri MDT At-Taqwa Kp. Ranca Ayu, Desa Maroko, Kabupaten Garut

Manusia sebagai pribadi yang unik adalah makhluk individu sekaligus makhluk sosial. Sebagai makhluk sosial, santri senantiasa berhubungan dan berkomunikasi atau santri melakukan interaksi sosial dengan orang lain. Seiring dengan perkembangan lingkungan sosial anak, interaksi sosial meliputi lingkup sosial yang lebih luas bukan hanya interaksi sosial dengan lingkungan keluarga saja melainkan dengan lingkungan sekolah dan dengan teman sebayanya. Anak-anak menghabiskan waktu bertahun-tahun di sekolah. Interaksi dengan guru dan teman sebaya di madrasah, memberikan suatu peluang yang besar bagi anak-anak untuk mengembangkan kemampuan kognitif serta keterampilan sosial yang dimilikinya.

Usia anak sekolah dasar merupakan ia di mana mereka sangat memperhatikan atau mementingkan akan penerimaan individu dalam sebuah ikatan pertemanan antar sebaya. Sebaya memegang peran yang unik dalam perkembangan anak karena mereka termasuk dalam tingkat umur dan kedewasaan yang kurang lebih sama. Sehingga bagaimanapun bagi anak usia sekolah, teman sebaya mempunyai fungsi yang hamper ssama dengan oragn tua. Teman bisa memberikan infromasi dan perbandingan tentang dunia luar keluarga. Teman bisa memberikan ketenangan ketika mengalami kekhawatiran. Tidak jarang terjadi seorang anak yang tadinya penakut berubah menjadi pemberani berkat teman sebaya.

Siswa yang memiliki interaksi sosial dengan teman sebaya tinggi memiliki keterbukaan individu dan dapat menjalin hubungan akrab yang mengakibatkan santri tersebut mudah diterima dalam kelompok manapun. Santri juga suka melibatkan dirinya dalam kegiatan kelompok seperti belajar kelompok dan kegiatan kelompok lainnya. Karena interaksi sosialnya tinggi membuat siswa tersebut pandai berkomunikasi 
dengan siapapun dan tidak segan-segan untuk memberikan ide bagi kemajuan kelompoknya serta saling berbicara dalam hubungan yang erat. Sering bertemunya santri dengan teman sebayanya di kelas maupun dimadrasah baik dalam kerjasama dalam kegiatan diskusi kelompok belajar atau sekedar kerjasama dalam sebuah permainan dapat menciptakan hubungan yang intens antar individu dan bisa saling mengenal lebih dalam satu sama lain.

Santri dengan kategori sedang adalah mereka yang memiliki intensitas bertemu dengan teman sebaya atau anggota kelompoknya tinggi karena sering bertemu baik di kelas maupun di luar kelas bisa dikatakan di luar madrasah pun mereka sering bertemu untuk berkumpul belajar kelompok atau sekedar bermain Bersama serta menghabiskan waktu luang atau liburan mereka. Seringnya mereka bertemu dapat memberikan kenyamanan orang disekitarnya, sehingga mereka bisa saling bicara dalam hubungan yang dekat seperti halnya membicarakan apa yang mereka sukai, tanya jawab tentang materi yang belum difahami atau lainnya. Selain itu, mereka memiliki keterbukaan individu dan suka memberikan ide atau pendapatnya untuk kemajuan kelompoknya.

Kategori terakhir adalah kategori rendah merupakan kategori paling sedikit yang dimiliki oleh santri. Artinya, dari jumlah santri yang ada, santri yang memiliki interaksi sosial rendah dengan teman sebaya bisa dikatakan relative wajar. Karena tidak mungkin dalam sebuah perkumpulan atau kelompok dari banyaknya santri yang ada di MDT At-Taqwa, semuanya memiliki keterampilan sosial dalam interaksi dengan teman sebaya yang positif. Oleh karenanya, penting adanya upaya dari pihak sekolah atau guru bahkan teman sebayanya dikelas untuk membantu mereka dalam meningkatkan interaksi sosial santri tersebut.

b) Tingkat Motivasi Belajar Santri MDT At-Taqwa Kp. Ranca Ayu, Desa Maroko, Kabupaten Garut

Belajar merupakan suatu kegiatan yang menjadi kebutuhan hidup manusia yang sangat penting. Dengan belajar santri dapat mengetahui hal-hal baru yang dapat mengubah perilaku atau atau pandangan mereka dari ketidaktahuan menjadi tahu, dari tidak bisa menjadi bisa. 
Belajar merupakan suatu proses perubahan tingkah laku sebagai akibat dari suatu pengalaman atau latihan. Belajar tidak akan dilakukan jika tidak adanya suatu dorongan kuat baik yang berasal dari dalam diri individu yang lebih utama maupun dari luar diri individu sebagai upaya lain yang tak kalah penting. Dorongan itulah yang disebut dengan motivasi.

Motivasi dan belajar merupakan dua hal yang saling mempengaruhi. Oleh karenanya motivasi sangat diperlukan dalam kegiatan belajar. Seseorang yang tidak mempunyai motivasi dalam belajar, tak akan mungkin melakukan aktivitas belajar. Segala sesuatu yang menarikminat orang lain belum tentu menarik minat orang tertentu selama sesuatu itu tidak bersentuhan dengan kebutuhan. Hal ini merupakan tanda bahwa sesuatu yang dikerjakan itu menyentuh kebutuhannya, yaitu kebutuhan belajar untuk mendapatkan ilmu pengetahuan.

Pada diri seseorang terdapat penentu tingkah laku yang bekerja untuk melakukan perubahan tingkah laku. Faktor penentu tersebut adalah motivasi atau daya penggerak tingkah laku manusia. Misalnya, santri yang berkemauan tinggi untuk belajar karena adanya penghargaan yang tinggi dalam belajar. Adanya penghargaan dalam belajar sepeti, nilai yang tinggi dapat memotivasi anak untuk lebih terpacu belajarnya.

Kemauan yang keras untuk belajar adalah adalah tanda dari santri yang memiliki motivasi belajar sangat tinggi. Santri yang memiliki motivasi tinggi merasa bahwa belajar sudah mnejadi kebutuhnnya karena bisa menambah pengetahuan baru. Santri yang memiliki motivasi belajar sangat tinggi biasanya memiliki rasa ingin tahu yang tinggi dan aktif bertanya dalam pembelajaran. Selain bermain dengan teman sebayanya, mereka juga menghabiskan waktunya untuk belajar baik kelompok maupun mandiri. Serta memiliki harapan penuh untuk bisa meraih cita-cita masa depan.

Santri yang termasuk dalam kategori sedang ini belum memaksimalkan motivasi intrinsik yang dimilikinya. Namun, hal tersebut tidak menjadikan kehilangan motivasi belajar karena mereka masih tergolong dalam motivasi sedang dan merupakan kategori terbanyak dalam penelitian ini. 
Kategori selanjutnya adalah kategori rendah, hasrat keinginan belajar pada anak kategori cukup lemah. Artinya, siswa memiliki kelemahan dalam memotivasi dirinya sendiri untuk melakukan aktivitas belajar. Hal tersebut bisa terjadi, karena mereka berpandangan bahwa belajar itu kurang menyenangkan atau kurang menarik sehingga hasrat mereka untuk belajar lemah. Anak dengan kategori rendah ini mudah merasa bosan jikan dia harus berlama-lama duduk tenang dikelas mendengarkan guru menyampaikan materi. Salah satu cara untuk membuat mereka kembali ke dunia belajar atau untuk menarik motivasi belajar mereka adalah dengan membuat aktivitas belajar itu menyenangkan.

c) Hubungan Interaksi Teman Sebaya dengan Motivasi belajar Santri MDT At-Taqwa Kp. Ranca Ayu, Desa Maroko, Kabupaten Garut

Antara teman sebaya dan motivasi belajar terdapat bubungan yang cukup kuat. Artinya, semakin tinggi tingkat interaksi teman sebaya yang dimiliki santri, semakin tinggi pula tingkat motivasi belajarnya.

Barker dan wright mencatat bahwa anak usia 7 sampai 11 tahun meluangkan lebih dari $40 \%$ waktunya untuk berinteraksi dengan teman sebayanya. Banyaknya waktu yang dihabiskan siswa Bersama temannya akan berpengaruh terhadap kegiatan kognitif maupun sosialnya. Teman sebaya merupakan faktor ekstern yang mempengaruhi motivasi belajar siswa. Mereka memberikan dorongan-dorongan untuk belajar, misalnya dengan membuat kelompok belajar atau siswa menjadikan temannya untuk bertanya tentang materi yang belum difahami.

Peranan teman sebaya merupakan faktor yang tidak kalah penting namun sering luput dari perhatian orang tua dan guru. Hubungan dengan teman sebaya memiliki sejumlah peran dalam perkembangan pribadi dan sosial anak. Selain teman sebaya berperan sebagai agen sosialisasi yang membantu membentuk perilaku dan keyakinan anak. Teman sebaya juga berperan sebagai sumber informasi selain dari keluarga. Teman sebaya yang ada di lingkungan madrasah maupun dalam lingkungan tempat tinggal dapat mempengaruhi perilaku dan persepsi anak terhadap belajar dan sekolah.

Motivasi belajar menjadi salah satu faktor yang turut menentukan belajar yang efektif. Winkel menjelaskan bahwa motivasi belajar 
merupakan keseluruhan daya gerak dalam diri santri yang menimbulkan kegiatan belajar sehingga tujuan tercapai. Santri yang memiliki motivasi tinggi akan mempunyai banyak energi untuk melakukan kegiatan belajar. Dengan demikian titik awal dari aktivitas belajar adalah adanya dorongan dan kebutuhan dalam belajar, adanya harapan dan cita-cita masa depan, adanya hasrat dan keinginan berhasil. Serta adanya lingkungan belajar yang kondusif, adanya kegiatan yang menarik dalam belajar dan adanya penghargaan dalam belajar.

Interaksi teman sebaya dapat meningkatkan motivasi belajar siswa khususnya santri yang motivasi intrinsiknya kurang. Dengan meningkatkan keterampilan sosialnya yaitu dalam berinteraksi akan memberikan kekuatan positif pada motivasi belajarnya.

Santri yang memiliki keterampilan sosial yang baik seperti dalam hal berinteraksi dengan teman sebaya di madrasah sering kali mereka memiliki sifat terbuka sehingga mudah diterima dalam pergaulan dan mempunyai motivasi yang positif. Sebaliknya siswa dengan keterampilan sosial dalam berinteraksi dengan teman sebaya atau merasa dikucilkan oleh teman maka motivasinya pun juga akan rendah karena dia merasa temannya sudah tidak peduli padanya. Hubungan interaksi teman sebaya di madrasah yang terjadi saat kegiatan belajar mengajar di kelas maupun di luar kelas memiliki peranan penting dalam menumbuhkan motivasi belajar yang dapat meningkatkan keaktifan dan keefektifan belajar.

\section{FAKTOR-FAKTOR YANG MEMPENGARUHI MOTIVASI BELAJAR}

Menurut Oemar Hamalik ada beberapa faktor yang mempengaruhi motivasi, baik motivasi instrinsik maupun motivasi ekstrinsik diantaranya:

1. Tingkat kesadaran siswa akan kebutuhan yang mendorong tingkah laku/perbuatannya dan kesadaran atas tujuan belajar yang hendak dicapai.

2. Sikap guru terhadap kelas, guru yang bersikap bijak dan selalu merangsang siswa untuk berbuat kearah suatu tujuan yang jelas dan bermakna bagi kelas. 
3. Pengaruh kelompok siswa. Bila pengaruh kelompok terlalu kuat maka motivasinya lebih cenderung ke sifat ekstrinsik.

4. Suasana kelas juga berbengaruh terhadap muncul sifat tertentu pada motivasi belajar siswa.

Belajar suatu tugas yang sangat erat dengan pelajar namun belum tentu hasil yang diperoleh pelajar setingkat dengan hasil yang sama. Hal ini menunjukkan adanya beberapa faktor yang mempengaruhi pelajar diantaranya menurut Sumadi Suryobroto adalah:

a) Faktor-faktor yang berasal dari luar diri si pelajar, yaitu:

1. Faktor-faktor non sosial

2. Faktor-faktor sosial

b) Faktor-faktor yang berasal dari dalam diri si pelajar;

1. Faktor-faktor fisiologis

2. Faktor-faktor psikologis Untuk lebih jelasnya penulis jelaskan faktorfaktor tersebut diatas:

o Faktor-faktor yang berasal dari luar diri si pelajar, yaitu:

1. Faktor - faktor non sosial Kelompok faktor ini antara lain misalnya: keadaan udara, suhu udara, cuaca, waktu, tempat, alat-alat yang dipakai untuk belajar.

2. Faktor- faktor sosial Faktor sosial adalah faktor manusia (sesama manusia), baik manusia itu hadir maupun kehadirannya itu dapat disimpulkan jadi kehadirannya tidak langsung.

o Faktor yang berasal dari dalam diri si pelajar, yaitu:

1. Faktor- faktor fisiologis Faktor ini masih dapat dibedakan menjadi dua macam yaitu:

a) Jasmani pada umumnya

b) Keadaan fungsi-fungsi fisiologis tertentu

2. Faktor-faktor psikologis

Menurut Arden N. Frandsen mengatakan bahwa hal yang mendorong seseorang untuk belajar itu adalah sebagai berikut:

a) Adanya sifat ingin tahu dan ingin menyelidiki dunia yang lebih luas

b) Adanya sifat yang kreatif yang ada pada manusia dan berkeinginan untuk selalu maju. 
c) Adanya keinginan untuk mendapatkan simpati dari orang tua, guru, dan teman-teman.

d) Adanya keinginan untuk mendapatkan rasa aman bila menguasai pelajaran.

Menurut Bimo Walgito faktor-faktor yang mempengaruhi belajar adalah:

- Faktor anak atau individu belajar

- Faktor lingkungan

- Faktor bahan / materi yang dipelajari.

Faktor-faktor tersebut di atas diperhatikan guna memperoleh hasil yang sebaik-sebaiknya. Untuk lebih jelasnya penulis jelaskan faktor-faktor menurut Bimo Walgito tersebut yaitu:

1) Faktor anak / individu belajar, yang termasuk dalam faktor ini adalah, kecerdasan, kesehatan dan kemampuan untuk belajar, hal ini dapat mempengaruhi dalam proses belajar mengajar.

2) Faktor lingkungan besar pengaruhnya terhadap proses belajar mengajar, seperti alat belajar, letak geografis, lingkungan, dan keadaan keluarga dan sebagainya. Untuk itu harus termasuk dalam perhitungan masalah lingkungan. Lingkungan harus diciptakan dalam tujuan pendidikan

3) Bahan atau materi pelajaran akan menentukan cara atau metode mempelajari antara bidang studi dengan demikian dibutuhkan metode yang berbeda, dengan pertimbangan antara minat, kesungguhan, semangat dan percaya diri.

Faktor-faktor tersebut harus diperhatikan sabab dari ketiga faktor tersebut menurut hemat penulis tidak bisa di pisah-pisahkan, bila salah satu belum terpenuhi, maka proses belajar mengajar tidak akan berjalan dengan baik. Sehubungan dengan motivasi, ada tiga hal yang perlu diperhatikan untuk meningkatkan proses belajar:

1) Motivasi jangka panjang. Seorang murid yang belajar secara tekun guna menghadapi ulangan umum atau ujian akhir, mempunyai motivasi jangka panjang. Setiap kali ia selalu memaksa diri untuk dapat mengerti hal yang dijelaskan oleh pengajarnya. Motivasi seperti ini mempunyai arti sama pentingnya dengan inteligensi yang baik. 
2) Motivasi jangka pendek. Motivasi jenis ini merupakan minat saat itu, yang dibutuhkan agar para pendengar mengerti penjelasan pengajar. Motivasi ini sangat dipengaruhi oleh motivasi jangka panjang. Dan sebaliknya motivasi jangka panjang memperoleh isi dari jangka pendek.

3) Kadar surut ingatan (regresi). Yang dimaksud dengan kadar surut ingatan atau regresi adalah proses melemahnya ingatan seseorang akan sesuatu hal. Siswa dengan kadar surut ingatan-ingatan yang tinggi mudah lupa akan masalah yang dijelaskan oleh pengajar. Seorang dapat memperkecil gresi siswa- siswanya atau mahasiswa dengan jalan menanamkan motivasi kepada mereka, baik motivasi jangka panjang ataupun motivasi jangka pendek. Tetapi regresi juga dapat berkurang apabila seorang mahasiswa mempunyai banyak kepentingan dengan hal yang diajarkan karena kepentingan dapat memperkuat motivasi seseorang.

\section{Upaya meningkatkan Motivasi Belajar Anak}

1. Peranan guru MDT At-Taqwa Kp. Ranca Ayu desa Maroko Kab Garut

Meningkatkan motivasi belajar santri adalah salah satu kegiatan intregral yang wajib ada dalam kegiatan pembelajaran. Selain memberikan ilmu pengetahuan dan mentransfer ilmu pengetahuan guru juga bertugas untuk meningkatkan motivasi anak dalam motivasi anak dalam belajar. Proses pembelajaran akan berhasil manakala santri mempunyai motivasi dalam belajar. Oleh karena itu, guru perlu menumbuhkan motivasi belajar santri. Untu memperoleh hasil belajar yang optimal, guru dituntut kreatif membangkitkan motivasi belajar santri. Berikut ini dikemukakan beberapa petunjuk untuk meningkatkan motivasi belajar santri:

a. Memperjelas tujuan yang ingin dicapai

Tujuan yang jelas dapat membuat santri paham kearah mana ia ingin dibawa. Pemahaman santri terhadap tujuan pembelajaran dapat menumbuhkan minat siswa untuk belajar yang pada gilirannya dapat meningkatkan motivasi belajar mereka.

b. Membangkitkan minat siswa 
Siswa akan terdorong untuk belajar manakala mereka memiliki minat untuk belajar. Mengembangkan minta belajar santri merupakan salah satu teknik dalam mengembangkan motivasi belajar.

c. Ciptakan suasana belajar yang menyenangkan dalam belajar

Santri mungkin dapat belajar baik manakala ada dalam suasana yang menyenangkan, merasa aman, bebas dari takut. Usahakan agar kelas selamanya dalam suasana hidup dan segar, terbebas dari rasa tegang. Untuk itu guru sekali-kali dapat melakukan hal-hal lucu.

d. Menggunakan variasi metode penyajian yang menarik

Guru harus mampu menyajikan informasi yang menarik, dana sing bagi santri-santri. Sesuatu informasi yang disampaikan dengan teknik yang baru, dengan kemasan yang bagus didukung oleh alat-alat berupa sarana atau media yang belum pernah dikenal oleh santri sebelumnya sehingga menarik perhatian bagi mereka untuk belajar.

e. Berilah pujian yang wajar setiap keberhasilan siswa

Motivasi akan tumbuh manakala santri merasa dihargai. Dalam pembelajaran, pujian dapat dimanfaatkan sebagai alat motivasi.

f. Berikan penilaian

Banyak santri yang belajar karena ingin memperoleh nilai bagus. Untuk itu mereka belajar dengan giat. Bagi sebagian santri nilai dapat menjadi motivasi yang kuat untuk belajar.

g. Berikan komentar terhadap hasil pekerjaan siswa

Siswa butuh penghargaan. Penghargaan bisa dilakukan dengan memberikan komentar yang positif.

2. Peranan Orang Tua santri

Untuk dapat memperoleh hasil belajar yang optimal dalam belajar maka seorang anak perlu mendapatkan motivasi baik intrinsik maupun ekstrinsik. oleh karena itu hendaknya orang tua senantiasa memotivasi anak agar lebih giat dalam belajar.

Ada beberapa cara yang dapat dilakukan oleh orang tua untuk menumbuhkan motivasi anak:

1. Mengetahui hasil

Dengan mengetahui hasil pekerjaan, apalagi kalua terjadi kemajuan akan mendorong anak untuk giat belajar. Semakin mengetahui bahwa grafik hasil belajar meningkat, maka ada motivasi pada diri anak untuk 
terus belajar, dengan suatu harapan hasilnya akan terus meningkat. Seorang anak biasanya akan merasa malu apabila prestasinya merosot, oleh karena itu orang tua hendaknya jangan segan-segan untuk menanyakan hasil yang dicapai oleh anaknya.

2. Memberi hadiah dan hukuman

Metode pemberian hadiah (reward) dikatakan sebagai motivasi yaitu apabila hadiah tersebut disukai oleh anak sekalipun kecil/murah harganya. Sebaliknya hadiah tidak akan disukai oleh anak atau anak tidak berbakat untuk suatu pekerjaan. Sebagai contoh hadiah yang diberikan untuk gambar yang terbaik, mungkin tidak akan menarik bagi anak yang tidak memiliki bakat menggambar. Demikian halnya dengan hukuman-hukuman dapat menjadi reinforcement yang negatif, tetapi kalua diberikan secara tepat dan bijaksana dapat menjadi alat motivasi.

3. Menyediakan alat atau fasilitas yang dibutuhkan

Kesediaan dari orang tua untuk memenuhi kebutuhan anaknya dalam belajar dapat mendorong anak untuk lebih giat belajar. Anak yang sedang belajar selain harus terpenuhi kebutuhan pokonya, juga membutuhkan fasilitas belajar seperti ruang belajar, meja, kursi, penerangan, alat tulis menulis, buku dan lain-lain.

\section{SIMPULAN}

1. Tingkat Interaksi Teman Sebaya Santri MDT At-Taqwa Kp. Ranca Ayu, Desa Maroko, Kabupaten Garut

Berdasarkan uraian data yang ada sebelumnya dalam upaya untuk menjawab rumusan masalah pertama, maka dapat disimpulkan bahwa tingkat interaksi teman sebaya santri MDT At-Takwa terbagi dalam tiga kategori, yaitu tinggi, sedang dan rendah. Sesuai dengan hasil penelitian dapat dinyatakan bahwa interaksi teman sebaya santri MDT At-Takwa tergolong sedang.

2. Tingkat Motivasi Belajar Santri MDT At-Takwa Kp. Ranca Ayu, Desa Maroko, Kabupaten Garut

Tingkat motivasi tergolong kedalam tiga kategori, yaitu tinggi, sedang dan rendah. Dari perbedaan kategori tersebut, sesuai dengan hasil penelitian dapat dinyatakan bahwa motivasi belajar santri MDT At-Takwa tergolong sedang. 
3. Hubungan Interaksi Teman Sebaya dengan Motivasi Belajar Santri MDT At-Takwa Kp. Ranca Ayu, Desa Maroko, Kabupaten Garut

Berdasarkan pemaparan hasil penelitian sebelumnya dapat diketahui bahwa hubungan tersebut termasuk kategori cukup kuat dengan sifat hubungan yang positif. Artinya, semakin tinggi tingkat interaksi teman sebaya yang dimiliki santri, maka semakin tinggi tingkat motivasi belajar santri. Sebaliknya semakin rendah tingkat interaksi teman sebaya yang di miliki santri, maka semakin rendah tingkat motivasi belajar santri.

\section{DAFTAR PUSTAKA}

Abu Ahmadi. (2000). Psikologi Sosial.Jakarta: Rineka Cipta.

Badrudin. (2013). Dasar-dasar Manajemen. Bandung: Alfabeta.

Dimyati dan Mudjiyono. (2009). Belajar dan Pembelajaran. Jakarta: Rineka Cipta.

Desmita. (2014). Psikologi Perkembangan. Bandung: Remaja Rosdakarya.

Hamzah B. Uno. (2015). Teori Motivasi dan Pengukurannya: Analisis di Bidang Pendidikan. Jakarta: Bumi Aksara.

John W Santrock. (2009). Psikologi Pendidikan. Jakarta: Salemba Humanika.

M. Dalyono. (2009). Psikologi Pendidikan. Jakarta: Rineka Cipta.

Oemar Hamalik. (2013). Proses Belajar Mengajar. Jakarta: Bumi Aksara.

Sardiman A.M. (2012). Interaksi dan Motivasi Belajar Mengajar. Jakarta: Grafindo

Slamet Santosa. (2006). Dinamika Kelompok. Jakarta: PT. Bumi Aksara Sugiyono. (2012). Statistika untuk Penelitian. Bandung: Alfabeta.

Suharsimi Arikunto. (2010). Prosedur Penelitian Suatu Pendekatan Praktik. Jakarta: Rineka Cipta.

Elsam,2014. UU No.20 Tahun 2003 Tentang Sistem Pendidikan Nasional.[online].(http:referensi.elsam.or.id/2014/11/uu-nomor20-tahun-2003-tentang-sistem-pendidikan-nasiona/, diakses tanggal 2 Agustus 2017). 